\title{
Evaluation of between-cow variation in milk urea and rumen ammonia nitrogen concentrations and the association with nitrogen utilization and diet digestibility in lactating cows
}

\author{
P. Huhtanen, ${ }^{* 1}$ E. H. Cabezas-Garcia, ${ }^{*}$ S. J. Krizsan, ${ }^{*}$ and K. J. Shingfield†‡ \\ *Department of Agricultural Research for Northern Sweden, Swedish University of Agricultural Sciences, S-90183 Umeå, Sweden \\ †Natural Resources Institute Finland, Animal Production Research, FI 31600 Jokioinen, Finland \\ †Institute of Biological, Environmental and Rural Sciences, Aberystwyth University, Aberystwyth, SY23 3EB, United Kingdom
}

\begin{abstract}
Concentrations of milk urea N (MUN) are influenced by dietary crude protein concentration and intake and could therefore be used as a biomarker of the efficiency of $\mathrm{N}$ utilization for milk production (milk $\mathrm{N} / \mathrm{N}$ intake; $\mathrm{MNE}$ ) in lactating cows. In the present investigation, data from milk-production trials (production data set; $\mathrm{n}=1,804 \mathrm{cow} /$ period observations from 21 change-over studies) and metabolic studies involving measurements of nutrient flow at the omasum in lactating cows (flow data set; $\mathrm{n}=450 \mathrm{cow} /$ period observations from 29 studies) were used to evaluate the influence of betweencow variation on the relationship of MUN with MNE, urinary $\mathrm{N}(\mathrm{UN})$ output, and diet digestibility. All measurements were made on cows fed diets based on grass silage supplemented with a range of protein supplements. Data were analyzed by mixed-model regression analysis with diet within experiment and period within experiment as random effects, allowing the effect of diet and period to be excluded. Between-cow coefficient of variation in MUN concentration and MNE was 0.13 and 0.07 in the production data set and 0.11 and 0.08 in the flow data set, respectively. Based on residual variance, the best model for predicting MNE developed from the production data set was MNE $(\mathrm{g} / \mathrm{kg})=238+$ $7.0 \times$ milk yield $(\mathrm{MY} ; \mathrm{kg} / \mathrm{d})-0.064 \times \mathrm{MY}^{2}-2.7 \times$ MUN (mg/dL) - 0.10 body weight $(\mathrm{kg})$. For the flow data set, including both MUN and rumen ammonia $\mathrm{N}$ concentration with MY in the model accounted for more variation in MNE than when either term was used with MY alone. The best model for predicting UN excretion developed from the production data set $(\mathrm{n}=443)$ was $\mathrm{UN}(\mathrm{g} / \mathrm{d})=-29+4.3 \times$ dry matter intake $(\mathrm{kg} / \mathrm{d})+$ $4.3 \times \mathrm{MUN}+0.14 \times$ body weight. Between-cow variation had a smaller influence on the association of MUN with MNE and UN output than published estimates of these relationships based on treatment means, in which
\end{abstract}

Received April 8, 2014.

Accepted January 28, 2015.

${ }^{1}$ Corresponding author: pekka.huhtanen@slu.se differences in MUN generally arise from variation in dietary crude protein concentration. For the flow data set, between-cow variation in MUN and rumen ammonia $\mathrm{N}$ concentrations was positively associated with total-tract organic matter digestibility. In conclusion, evaluation of phenotypic variation in MUN indicated that between-cow variation in MUN had a smaller effect on MNE compared with published responses of MUN to dietary crude protein concentration, suggesting that a closer control over diet composition relative to requirements has greater potential to improve MNE and lower UN on farm than genetic selection.

Key words: dairy cow, digestibility, milk urea, rumen ammonia, urinary nitrogen excretion

\section{INTRODUCTION}

Dairy farming is known to cause atmospheric and hydrospheric pollution (Tamminga, 1992). Animal manure contributes to $\mathrm{N}$ pollution as ammonia and nitrous oxide volatilization into the atmosphere, nitrate leakage in ground water, and $\mathrm{N}$ runoff in surface water. Despite considerable research effort to improve the efficiency of $\mathrm{N}$ utilization for milk production (milk $\mathrm{N} / \mathrm{N}$ intake; MNE), the conversion of dietary $\mathrm{N}$ into milk protein is relatively low. Over a wide range of diets, MNE averaged 247 and $277 \mathrm{~g} / \mathrm{kg}$ in lactating cows fed diets typical for North America and north Europe, respectively (Huhtanen and Hristov, 2009). However, considerable variation in MNE between individual cows and across different diets highlights the potential for improving $\mathrm{N}$ utilization. Overfeeding of dietary $\mathrm{CP}$ is often the main reason for low MNE. Increased dietary $\mathrm{CP}$ intake has been shown to exponentially increase the proportion of $\mathrm{N}$ excreted in urine (Kebreab et al., 2002). Therefore, accurate determination of ruminant protein requirements and the supply of AA available for absorption are critical for optimizing animal performance, while minimizing $\mathrm{N}$ inputs and $\mathrm{N}$ emissions from milk-production systems. Under commercial conditions, monitoring the adequacy of $\mathrm{CP}$ in the diet requires the use of reliable diagnostic biomarkers. Urea 
in blood is the major end product of $\mathrm{N}$ metabolism in ruminants. Even though BUN concentration could be used as an indicator of efficient $\mathrm{N}$ utilization, it cannot be measured routinely on farm.

Concentrations of urea in milk and blood are closely associated in lactating cows (Broderick and Clayton, 1997). Several studies have provided evidence to support the measurement of MUN concentration in bulktank milk as a useful indicator of on-farm efficiency of N utilization and urinary N (UN) output (Jonker et al., 1998; Kauffman and St-Pierre, 2001; Kohn et al., 2002). Extensive evaluation of experimental data has identified dietary $\mathrm{CP}$ content as the major factor influencing MUN concentration (Nousiainen et al., 2004). Dietary CP content has also been reported to be a better predictor of MUN concentration (Nousiainen et al., 2004) and UN excretion (Spek et al., 2013) than estimates of protein balance in the rumen or RDP supply in excess of predicted requirements, respectively. Across a range of diets, increases in MUN concentration have been shown to be associated with a curvilinear increase in milk protein yield, reaching a nadir around $25 \mathrm{mg} / \mathrm{dL}$, and a quadratic decrease in MNE (Nousiainen et al., 2004). Such relationships highlight that the marginal increase in milk protein yield and the associated decline in MNE to additional dietary CP can be expected to be greater for cows producing milk with a low MUN concentration. Evaluation of $\mathrm{N}$ intake and flow of $\mathrm{N}$ at the omasum measured in cows fed a range of diets indicated that zero rumen $\mathrm{N}$ balance was associated with an average MUN concentration of 8.3 $\mathrm{mg} / \mathrm{dL}$ (Broderick et al., 2010), with the implication that a MUN below this concentration might reflect a deficiency in RDP.

Most assessments of the potential of measuring MUN concentrations as a diagnostic of MNE and biomarker of $\mathrm{N}$ metabolism and UN output in lactating cows have been based on treatment means (Jonker et al., 2002; Nousiainen et al., 2004; Spek et al., 2013). However, a recent study reported differences in MUN concentration that were not explained by variations in dietary CP intake, milk yield, or BW (Aguilar et al., 2012), with the corollary that measurements of MUN may not be a robust biomarker for individual cows or a useful phenotyping tool in genetic selection for improved MNE or lower UN output. Even though variation in MUN concentration due to cow is widely recognized (Wattiaux et al., 2005; Stoop et al., 2007; König et al., 2008), the influence of between-cow variation on the association of MUN concentrations with MNE, UN, or overall $\mathrm{N}$ metabolism is not well defined. The objective of this study was to characterize the extent of betweenanimal variation in the concentrations of MUN or rumen ammonia nitrogen (RAN), and the influence of between-cow variation on the association of these parameters with MNE, UN excretion, and total-tract diet digestibility. Evaluations were made on data from milk-production trials and metabolic studies in lactating cows using mixed-model regression analysis that allowed the effects of diet and period to be removed.

\section{MATERIALS AND METHODS}

\section{Experimental Data}

Evaluations were performed using 2 data sets, one based on measurements from cows used in milk-production trials and the other containing a smaller set of more detailed measurements from metabolic studies in lactating cows. The production data set (Supplemental Table S1, http://dx.doi.org/10.3168/jds.2014-8215) comprised individual cow/period observations ( $\mathrm{n}=$ 1,978) obtained from 21 change-over milk-production trials. Data originated from 4 production trials conducted in Sweden, 2 in Norway, and 15 in Finland. All production trials were conducted as either Latin square or cyclic change-over designs. In 17 trials, forages were fed ad libitum and concentrates were offered on a flatrate basis, whereas in the rest a TMR was offered ad libitum. Grass silage was the main forage component for all diets, but in 6 trials, grass silage was partially replaced with red clover or whole-crop cereal silages. Concentrate supplements contained oats and barley, fibrous by-products from the food industry, and protein supplements, typically soybean meal, and rapeseed meal or rapeseed expeller. All rapeseed feeds were of double-zero varieties with low glucosinolate content. Measurements included parity (primiparous or multiparous), DIM, BW, feed intake, diet chemical composition, including silage fermentation characteristics, milk yield, milk composition, and MUN concentration. Determinations of diet chemical composition and measurements of DMI were used to calculate the supplies of ME and MP using the Finnish feed evaluation system (MTT, 2013). The yield of ECM was calculated according to Sjaunja et al. (1991). For 9 milk-production trials MUN concentrations were determined as ammonia following urease hydrolysis (McCullough, 1967) in a single laboratory. Concentrations of MUN in the other 12 milk-production trials was measured by infrared spectroscopy (MilkoScan 6000, Foss Electric, Hillerød, Denmark) in 3 different laboratories. Observations (n $=174$ ) for cows $<20$ DIM, producing $<10 \mathrm{~kg}$ of milk $/ \mathrm{d}$, with a calculated ME balance of $>+50 \mathrm{MJ} / \mathrm{d}$ or $<-50$ $\mathrm{MJ} / \mathrm{d}$ were excluded from the production data set.

Total-tract diet digestibility $(\mathrm{n}=443)$ was determined in 10 milk-production trials. Measurements of diet di- 
gestibility for individual cows were made on average for $50 \%$ of the animals recruited to a milk-production trial based on twice-daily collection of spot fecal samples over $5 \mathrm{~d}$ using acid insoluble ash as an internal marker (Van Keulen and Young, 1977). Urinary N excretion was not measured but calculated as

$$
\mathrm{UN}=\mathrm{N} \text { intake }- \text { fecal } \mathrm{N}-\text { milk } \mathrm{N}-\text { retained } \mathrm{N} .
$$

Retained $\mathrm{N}$ was estimated from calculated ME balance assuming that for cows in positive energy balance, 1.0-kg-of-BW change was equivalent to $34 \mathrm{MJ}$ of $\mathrm{ME}$, whereas $1.0-\mathrm{kg}$-of-BW change during periods of negative energy balance was equivalent to $28 \mathrm{MJ}$ (MTT, 2013). Each kilogram of BW change was assumed to contain $160 \mathrm{~g}$ of CP (MTT, 2013).

Data from metabolic studies in lactating cows (flow data set) included measurements of nutrient intake, rumen fermentation characteristics, nutrient flow at the omasum, milk yield, and milk composition (Supplemental Table S2, http://dx.doi.org/10.3168/ jds.2014-8215). The flow data set comprised $450 \mathrm{cow} /$ period observations from 29 experiments. Total-tract diet digestibility was determined by total fecal collection in 23 experiments or from the collection of spot fecal samples using acid insoluble ash as a marker in 6 experiments. Measurements of nutrient flow at the omasum were made in 22 studies $(\mathrm{n}=331)$ using the omasal sampling technique and a triple-marker system. Concentrations of RAN were determined in all 29 experiments $(\mathrm{n}=450)$. In 20 studies, MUN concentration was measured by urease hydrolysis (McCullough, 1967) in a single laboratory. For all 29 metabolic studies, cows were offered diets of similar composition to that fed in the milk-production trials.

\section{Statistical Analysis}

Estimates of variance components were evaluated using the PROC MIXED procedure of SAS (version 9.3; SAS Institute Inc., Cary, NC) with experiment $(\mathbf{E x p})$, diet within experiment $[\operatorname{Diet}(\mathbf{E x p})]$, period within experiment $[\operatorname{Period}(\mathbf{E x p})]$, and cow within experiment $[\operatorname{Cow}(\mathbf{E x p})]$ as random factors. Covariance structure was specified using the TYPE $=\mathrm{VC}$ option in the RANDOM statement. The standard deviation and coefficient of variation for each factor (Tables 3 and 4) were calculated as the square root of the variance estimate and standard deviation divided by the respective mean value of each factor (Tables 1 and 2), respectively.

Repeatability values (Rep) for MUN and RAN concentrations were calculated as

$$
\operatorname{Rep}=\sigma_{\text {Cow }}^{2} /\left(\sigma_{\text {Cow }}^{2}+\sigma_{\text {Residual }}^{2}\right),
$$

where $\sigma_{\text {Cow }}^{2}$ and $\sigma_{\text {Residual are }}^{2} \operatorname{Cow}(\operatorname{Exp})$ and residual variances, respectively. Repeatability values provide an estimate of the correlation between values from consecutive samples on the same cow, on the same diet, and within the same period of the same experiment.

To explore the relationships between the variables of interest [MUN, MNE, UN, total-tract OM digestibility (OMD), and total-tract NDF digestibility (NDFD)], data were analyzed by regression analysis within the MIXED procedure of SAS (Littell et al., 2006) using the following model:

$$
\begin{aligned}
Y_{i j}=B_{0} & +B_{1} X_{1 i j}+b_{0}+b_{1} X_{1 i j}+B_{2} X_{2 i j} \\
& +B_{3} X_{3 i j}+B_{4} X_{4 i j}+e_{i j},
\end{aligned}
$$

where $Y_{i j}=$ the expected value for the dependent variable $Y$ observed at level of $j$ of the independent variable $X$ in the study $i ; B_{0}=$ the overall intercept (fixed effect); $b_{0}=$ the random effect of study $i$ on the intercept $(i=1, \ldots, 21$ for the production data set; $i=$ $1, \ldots, 29$ for the flow data set); $B_{1}, \ldots, B_{4}$ are regression coefficients of $Y$ on $X_{1}, \ldots, X_{4}$ of $Y$ across all studies (fixed effects); $X_{1 i j}, \ldots, X_{4 i j}=$ value $j$ of the continuous variable $X_{1}, \ldots, X_{4}$ in study $i ; b_{i}=$ the random effect of study $i$ on the regression coefficient of $Y$ on $X_{1}$ in study $i(i=1, \ldots, 21$ for the production data set; $i=1, \ldots$, 29 for the flow data set); and $e_{i j}=$ the residual error.

In different models, the number of independent variables varied between 1 and 4 . The model included 2 random statements: a random intercept and slope of $X_{1}$ with SUBJECT $=$ Diet(Exp), and a random intercept with SUBJECT $=$ Period(Exp), using the TYPE $=\mathrm{VC}$ (variance components) covariance structure for both random statements. The method $=$ ML (maximum likelihood) statement was used in the PROC MIXED model syntax. Only one random independent variable was used to avoid overparameterized models and improve convergence (St-Pierre, 2001). The models were evaluated on the basis of Akaike's information criterion with correction (AICc) and residual variance. Syntaxes of statistical programs are available in Supplemental Table S3 (http://dx.doi.org/10.3168/jds.2014-8215).

\section{RESULTS}

\section{Evaluation Data Sets}

Mean diet characteristics and animal variables for the production data set are shown in Table 1. Both animal and diet parameters exhibited considerable variation and covered the range in dietary chemical composition relevant to commercial milk production. Variation in 
Table 1. Description of diet composition, intake, and milk yield and composition for the production data set derived from 21 milk-production trials $(\mathrm{n}=1,804)$

\begin{tabular}{lcccc}
\hline Item & Mean & SD & Minimum & Maximum \\
\hline Intake, kg/d & & & & \\
Forage DM & 12.5 & 2.35 & 4.1 & 21.0 \\
Concentrate DM & 8.3 & 2.39 & 2.5 & 14.6 \\
Total DM & 20.8 & 3.04 & 10.9 & 30.2 \\
ME intake, MJ/d & 236 & 36.5 & 113 & 352 \\
ME balance, MJ/d & 14 & 17.5 & -48 & 50 \\
MP supply, kg/d & 1.96 & 0.324 & 0.87 & 3.02 \\
Diet composition & & & & \\
OM, g/kg of DM & 925 & 9.7 & 887 & 948 \\
CP, g/kg of DM & 162 & 19.7 & 111 & 220 \\
NDF, g/kg of DM & 437 & 41.6 & 313 & 563 \\
ME, MJ/kg of DM & 11.3 & 0.44 & 10.2 & 12.4 \\
Milk yield and composition & & & & \\
Milk, kg/d & 29.7 & 6.42 & 10.1 & 51.1 \\
ECM, kg/d & 30.9 & 5.88 & 12.2 & 52.3 \\
Fat, g/kg $/ \mathrm{kg} / \mathrm{d}$ & 43.7 & 6.23 & 27.3 & 66.6 \\
Protein, g/kg & 33.7 & 3.16 & 25.4 & 46.8 \\
Lactose, g/kg & 47.7 & 2.19 & 38.3 & 54.8 \\
MUN, mg/dL & 12.0 & 3.52 & 2.2 & 28.8 \\
MNE, g/kg & 296 & 39.7 & 176 & 444 \\
Feed efficiency, kg of ECM/kg of DMI & 1.48 & 0.158 & 0.91 & 2.22 \\
BW, kg & 609 & 68.8 & 443 & 822 \\
DIM & 131 & 51.6 & 23 & 349 \\
\hline
\end{tabular}

${ }^{1}$ Efficiency of $\mathrm{N}$ utilization for milk production defined as milk $\mathrm{N} / \mathrm{N}$ intake.

these parameters was similar in the flow data set (Table $2)$. For both data sets, the range in diet composition was similar, whereas average DMI and milk yield were 1.4 and $2.6 \mathrm{~kg} / \mathrm{d}$ lower in the production compared with the flow data set, respectively. Concentrations of MUN for individual cows varied substantially $(\mathrm{CV}=$ 0.286 and 0.317 in the production and flow data sets, respectively).

Variance estimates of dependent variables for the production and flow data sets are presented in Tables 3 and 4, respectively. Differences between experiments was the largest source of variation in the production data set (Table 3), reflecting the differences in diet composition between experiments and variance introduced by differences in analytical methods. Least squares means of MUN concentration using $\mathrm{CP}$ and ME intakes as covariates were 9.5, 8.9, and $13.1 \mathrm{mg} /$ $\mathrm{dL}$ for the 3 participating laboratories using infrared reflectance spectroscopy ( $\mathrm{n}=240,124$, and 705 , respectively), and $12.0 \mathrm{mg} / \mathrm{dL}$ for the laboratory using urease hydrolysis $(\mathrm{n}=735)$.

For MUN concentration, the extent of between-cow variability and variation due to Diet(Exp) for the production data set were of a similar magnitude $(\mathrm{CV}=$ 0.132 and 0.125 , respectively; Table 3 ). Repeatability of MUN concentration (0.66) in the production data set was substantially lower than for milk fat (0.76) or milk protein (0.91) content.

Estimates of variance components for MNE were similar in the production and flow data sets (Tables
3 and 4, respectively), with the exception of greater between-study variability in the flow data set $(0.122$ vs. 0.076). For both data sets, variation in MNE was smaller than for MUN concentration (Tables 1 and 2).

Concentration of RAN in the flow data set was more variable $(\mathrm{CV}=0.515$; Table 2$)$ than MUN concentration in both the production and flow data sets (Tables 1 and 2). The variance component of RAN concentration (Table 4) associated with Cow(Exp) was highly significant $(P<0.001)$ and of greater magnitude than for MUN concentration in the same data set $(\mathrm{CV}=$ 0.144 vs. 0.106$)$. Total variance of MNE and its distribution were similar in both data sets (Tables 3 and 4). Experiment and Diet(Exp) were the largest sources of variation in calculated UN output (Table 3). Betweencow variability in $\mathrm{OMD}$ was rather small $(\mathrm{CV}=0.012$ and 0.016 in the production and flow data sets, respectively).

\section{Nitrogen Intake and Excretion}

Distribution of $\mathrm{N}$ intake in the production data set is shown in Table 5. The proportion of $\mathrm{N}$ intake lost in urine exhibited more variation compared with other routes of $\mathrm{N}$ excretion (Table 5). Partitioning of $\mathrm{N}$ intake in milk was lower than for feces. Regression based on the mixed model analysis of milk $\mathrm{N}$, fecal $\mathrm{N}$, and urine $\mathrm{N}$ output or retained $\mathrm{N}$ against $\mathrm{N}$ intake indicated that incremental increases in $\mathrm{N}$ intake were partitioned in milk (0.262 \pm 0.005$)$, feces $(0.272 \pm 0.012)$, urine $(0.374$ 
Table 2. Description of diet composition, intake, milk production, total-tract nutrient digestibility, and $\mathrm{N}$ flow at the omasum for the flow data set derived from 29 metabolic studies in lactating cows

\begin{tabular}{|c|c|c|c|c|c|}
\hline Item & $\mathrm{n}$ & Mean & SD & Minimum & Maximum \\
\hline \multicolumn{6}{|l|}{ Intake, $\mathrm{kg} / \mathrm{d}$} \\
\hline Forage DM & 450 & 11.8 & 2.42 & 2.5 & 18.8 \\
\hline Concentrate DM & 450 & 7.7 & 2.46 & 0.0 & 17.3 \\
\hline Total DM & 450 & 19.5 & 2.73 & 11.4 & 27.5 \\
\hline \multicolumn{6}{|l|}{ Diet composition } \\
\hline $\mathrm{CP}, \mathrm{g} / \mathrm{kg}$ of $\mathrm{DM}$ & 450 & 159 & 21.0 & 126 & 239 \\
\hline $\mathrm{NDF}, \mathrm{g} / \mathrm{kg}$ of $\mathrm{DM}$ & 450 & 401 & 55.6 & 288 & 534 \\
\hline \multicolumn{6}{|l|}{ Milk yield and composition } \\
\hline Milk, kg/d & 450 & 27.2 & 6.99 & 5.0 & 44.6 \\
\hline $\mathrm{ECM}, \mathrm{kg} / \mathrm{d}$ & 450 & 27.2 & 6.24 & 5.2 & 47.4 \\
\hline Fat, $\mathrm{g} / \mathrm{kg}$ & 450 & 40.6 & 6.04 & 16.5 & 55.9 \\
\hline Protein, $\mathrm{g} / \mathrm{kg}$ & 450 & 33.4 & 3.97 & 21.3 & 58.0 \\
\hline Lactose, $\mathrm{g} / \mathrm{kg}$ & 450 & 47.8 & 2.20 & 37.1 & 53.7 \\
\hline MUN, mg/dL & 309 & 10.2 & 3.24 & 3.3 & 21.1 \\
\hline $\mathrm{MNE},{ }^{1} \mathrm{~g} / \mathrm{kg}$ & 450 & 291 & 51.9 & 95 & 475 \\
\hline $\mathrm{BW}, \mathrm{kg}$ & 295 & 624 & 64.5 & 459 & 789 \\
\hline \multicolumn{6}{|l|}{ Total-tract digestibility, $\mathrm{g} / \mathrm{kg}$} \\
\hline $\mathrm{OM}$ & 414 & 739 & 34.4 & 641 & 857 \\
\hline $\mathrm{CP}$ & 414 & 683 & 51.5 & 519 & 876 \\
\hline $\mathrm{NDF}$ & 414 & 648 & 69.2 & 447 & 828 \\
\hline \multicolumn{6}{|l|}{ Flow at the omasum } \\
\hline NAN, g/d & 331 & 474 & 100.8 & 226 & 667 \\
\hline Microbial N, g/d & 331 & 311 & 72.4 & 112 & 496 \\
\hline Microbial N, g/kg of DOMR ${ }^{2}$ & 295 & 24.5 & 3.81 & 15.4 & 37.0 \\
\hline $\mathrm{RAN}^{3} \mathrm{mg} / \mathrm{dL}$ & 450 & 9.7 & 5.01 & 2.0 & 34.0 \\
\hline
\end{tabular}

$\pm 0.018)$, and body tissues $(0.056 \pm 0.004)$. Mean estimated $\mathrm{N}$ retention in the production data set was close to zero $(+8 \mathrm{~g} / \mathrm{d}$; Table 5$)$.

For the 10 milk-production trials where total-tract digestibility was measured $(\mathrm{n}=443)$, regression of apparent digestible $\mathrm{N}$ against dietary $\mathrm{N}$ concentration basis estimated true $\mathrm{N}$ digestibility (slope) and metabolic fecal $\mathrm{N}$ excretion (intercept) as $0.911 \pm 0.040$ and -5.8 $\pm 1.10 \mathrm{~g} / \mathrm{kg}$ of DMI, respectively.

\section{Factors Influencing MUN Concentration}

Including Diet(Exp) and Period(Exp) effects in the statistical analysis allowed for an evaluation of animal factors influencing MUN in lactating cows independent of dietary treatment or experimental period. For the production data set, MUN concentration increased $(P$ $<0.001)$ with increases in the yields of milk and ECM (Table 6). Furthermore, MUN concentration was associated negatively $(P<0.001)$ with milk protein concentration, whereas no relation existed $(P>0.05)$ between the concentrations of MUN and milk fat concentration. Increases in DIM had a quadratic effect $(P<0.01)$ on MUN concentration, reaching a maximum on d 123 postpartum. In a bivariate model, MUN concentration was positively associated with milk yield and negatively with milk protein concentration. Calculated ME bal- ance had no influence $(P>0.05)$ on MUN concentration (data not presented).

\section{Factors Influencing Efficiency of Nitrogen Utilization}

In the production data set, MNE was positively associated $(P<0.001)$ with milk yield and negatively related $(P<0.001)$ with MUN concentration (Table $7)$. The effects of these factors were additive. Based on residual variance, statistical models resulted in a better fit when both milk yield and MUN concentration were included as independent variables. Both DIM and BW had a negative influence on MNE. The model with the best fit included milk yield, MUN concentration, and BW as independent variables. In the flow data set, MNE was positively associated with milk yield and negatively related to MUN concentration (Table 8). Analysis of the flow data set for experiments $(\mathrm{n}=19)$ in which both RAN and MUN were analyzed $(\mathrm{n}=309)$ indicated that the concentration of RAN resulted in a slightly better prediction of MNE compared with MUN concentration. However, based on the AICc for each model, the prediction of MNE was improved when the concentrations of both MUN and RAN were included in the model as independent variables, particularly when milk yield was also included in the model (Table 8). 
Table 3. Variance-component estimates of MUN concentration, efficiency of $\mathrm{N}$ utilization for milk production (MNE), urinary N (UN) output, and total-tract OM digestibility (OMD) for lactating cows, developed using the production data set derived from 21 milk-production trials

\begin{tabular}{|c|c|c|c|c|c|}
\hline Item $^{1}$ & Estimate & $\mathrm{SE}$ & $\operatorname{Pr}>Z^{2}$ & $\mathrm{SD}^{3}$ & $\mathrm{CV}^{4}$ \\
\hline \multicolumn{6}{|c|}{ MUN, mg/dL, n = 1,804 } \\
\hline Exp & 5.41 & 1.909 & 0.002 & 2.325 & 0.194 \\
\hline Period(Exp) & 0.80 & 0.159 & $<0.001$ & 0.893 & 0.075 \\
\hline $\operatorname{Diet}(\operatorname{Exp})$ & 2.23 & 0.282 & $<0.001$ & 1.493 & 0.125 \\
\hline Cow (Exp) & 2.49 & 0.189 & $<0.001$ & 1.579 & 0.132 \\
\hline Residual & 1.28 & 0.056 & $<0.001$ & 1.133 & 0.095 \\
\hline \multicolumn{6}{|c|}{ MNE, $\mathrm{g} / \mathrm{kg}, \mathrm{n}=1,804$} \\
\hline Exp & 502 & 197.9 & 0.006 & 22.4 & 0.076 \\
\hline Period(Exp) & 182 & 36.5 & $<0.001$ & 13.5 & 0.046 \\
\hline $\operatorname{Diet}(\operatorname{Exp})$ & 367 & 46.2 & $<0.001$ & 19.2 & 0.065 \\
\hline Cow (Exp) & 382 & 29.4 & $<0.001$ & 19.5 & 0.066 \\
\hline Residual & 217 & 9.5 & $<0.001$ & 14.7 & 0.050 \\
\hline \multicolumn{6}{|c|}{ UN output, $\mathrm{g} / \mathrm{d}, \mathrm{n}=443$} \\
\hline Exp & 1,594 & 826.2 & 0.027 & 39.9 & 0.206 \\
\hline Period(Exp) & 60 & 22.1 & 0.003 & 7.8 & 0.040 \\
\hline $\operatorname{Diet}(\operatorname{Exp})$ & 965 & 159.0 & $<0.001$ & 31.1 & 0.161 \\
\hline Cow (Exp) & 260 & 47.2 & $<0.001$ & 16.1 & 0.083 \\
\hline Residual & 262 & 25.2 & $<0.001$ & 16.2 & 0.084 \\
\hline \multicolumn{6}{|c|}{ OMD, $\mathrm{g} / \mathrm{kg}, \mathrm{n}=443$} \\
\hline Exp & 444 & 233.0 & 0.028 & 21.1 & 0.030 \\
\hline Period(Exp) & 87 & 27.7 & 0.001 & 9.3 & 0.013 \\
\hline $\operatorname{Diet}(\operatorname{Exp})$ & 213 & 41.3 & $<0.001$ & 14.6 & 0.020 \\
\hline Cow (Exp) & 77 & 19.8 & $<0.001$ & 8.8 & 0.012 \\
\hline Residual & 203 & 19.6 & $<0.001$ & 14.3 & 0.020 \\
\hline
\end{tabular}

\section{Factors Influencing UN Excretion}

In the production data set, total DMI was the best single predictor of UN excretion based on residual variance and the AICc (Table 9). Output of UN was positively $(P<0.001)$ related to MUN concentration. The regression coefficient remained rather constant (4.3 to 5.8) when MUN was used as the sole independent variable or when included in the model containing other animal variables. The regression coefficients for MUN remained similar when milk yield was used as the only independent variable or when both milk yield and MUN concentration were used to predict UN output ( 2.8 vs. $2.7 \mathrm{~g} / \mathrm{d}$ per $\mathrm{kg} / \mathrm{d}$, respectively). Predictions of UN excretion were improved further by including DIM or $\mathrm{BW}$ as the third independent variable.

\section{Factors Influencing Feed Efficiency and Total-Tract Digestibility}

The influence of MUN concentration on feed efficiency was $0.010 \pm 0.0036 \mathrm{~kg}$ of $\mathrm{ECM} / \mathrm{kg}$ of DMI per unit change in MUN $(\mathrm{mg} / \mathrm{dL} ; P<0.01)$ when milk yield and MUN concentration were used as independent variables. In the flow data set, the influence of
MUN or RAN concentration was positively associated with improvements in total-tract OMD (Table 10).

The coefficients for MUN and RAN remained unchanged when total DMI was included in the model (Table 10). Quantitatively, the effect of RAN concentration on NDFD was greater than on OMD (3.9 vs. 1.4 $\mathrm{g} / \mathrm{kg}$ per $\mathrm{mg} / \mathrm{dL}$ ). A positive relationship also existed between MUN concentration and NDFD (model not reported). No relationship $(P>0.10)$ was found between RAN concentration and the digestibility of neutral detergent solubles (models not shown). Furthermore, the concentration of MUN or RAN had no influence $(P>$ $0.10)$ on the flows of NAN or microbial $\mathrm{N}$ at the omasum (models and regression equations not presented).

\section{DISCUSSION}

Concentrations of MUN are influenced by dietary $\mathrm{CP}$ concentration and intake, are closely correlated with UN excretion, and can be measured at a low cost, and are therefore attractive as a biomarker of protein intake relative to requirements in lactating dairy cows (Nousiainen et al., 2004). However, the value of MUN concentration as a diagnostic of protein feeding for an individual cow or as a suitable phenotype for genetic 
Table 4. Variance-component estimates of MUN concentration, efficiency of $\mathrm{N}$ utilization for milk production (MNE), rumen ammonia $\mathrm{N}$ concentration (RAN), and total-tract OM digestibility (OMD) developed using the flow data set derived from 29 metabolic studies in lactating cows

\begin{tabular}{|c|c|c|c|c|c|}
\hline Item $^{1}$ & Estimate & SE & $\operatorname{Pr}>Z^{2}$ & $\mathrm{SD}^{3}$ & $\mathrm{CV}^{4}$ \\
\hline \multicolumn{6}{|c|}{ MUN, mg/dL, n = 309} \\
\hline $\operatorname{Exp}$ & 3.86 & 1.725 & 0.013 & 1.964 & 0.193 \\
\hline Period(Exp) & 1.08 & 0.277 & $<0.001$ & 1.038 & 0.102 \\
\hline $\operatorname{Diet}(\operatorname{Exp})$ & 2.83 & 0.619 & $<0.001$ & 1.683 & 0.165 \\
\hline Cow(Exp) & 1.19 & 0.281 & $<0.001$ & 1.092 & 0.107 \\
\hline Residual & 1.26 & 0.160 & $<0.001$ & 1.125 & 0.110 \\
\hline \multicolumn{6}{|c|}{ MNE, $\mathrm{g} / \mathrm{kg}, \mathrm{n}=450$} \\
\hline $\operatorname{Exp}$ & 1156 & 383.3 & 0.001 & 34.0 & 0.117 \\
\hline Period(Exp) & 221 & 50.7 & $<0.001$ & 14.9 & 0.051 \\
\hline $\operatorname{Diet}(\operatorname{Exp})^{2}$ & 317 & 66.2 & $<0.001$ & 17.8 & 0.061 \\
\hline $\operatorname{Cow}(\operatorname{Exp})$ & 505 & 89.4 & $<0.001$ & 22.5 & 0.077 \\
\hline Residual & 361 & 38.4 & $<0.001$ & 19.0 & 0.065 \\
\hline \multicolumn{6}{|c|}{$\mathrm{RAN}, \mathrm{mg} / \mathrm{dL}, \mathrm{n}=450$} \\
\hline $\operatorname{Exp}$ & 14.28 & 4.310 & 0.001 & 3.779 & 0.389 \\
\hline Period(Exp) & 1.81 & 0.396 & $<0.001$ & 1.346 & 0.138 \\
\hline $\operatorname{Diet}(\operatorname{Exp})$ & 2.29 & 0.482 & $<0.001$ & 1.514 & 0.156 \\
\hline Cow (Exp) & 1.91 & 0.399 & $<0.001$ & 1.382 & 0.142 \\
\hline Residual & 2.82 & 0.294 & $<0.001$ & 1.679 & 0.173 \\
\hline \multicolumn{6}{|c|}{ OMD, $\mathrm{g} / \mathrm{kg}, \mathrm{n}=414$} \\
\hline $\operatorname{Exp}$ & 491 & 180.2 & 0.003 & 22.2 & 0.030 \\
\hline Period(Exp) & 112 & 28.0 & $<0.001$ & 10.6 & 0.014 \\
\hline $\operatorname{Diet}(\operatorname{Exp})$ & 229 & 47.7 & $<0.001$ & 15.1 & 0.020 \\
\hline Cow (Exp) & 132 & 31.0 & $<0.001$ & 11.5 & 0.016 \\
\hline Residual & 214 & 23.6 & $<0.001$ & 14.6 & 0.020 \\
\hline
\end{tabular}

selection for improved MNE or lower UN excretion is dependent on the extent of between-animal variation that cannot be explained by diet, level of production, or stage of lactation (Aguilar et al., 2012). Variability in MUN concentration $(\mathrm{CV}=0.30)$ in the production and flow data sets was similar to that reported for measurements made on commercial farms (Wattiaux et al., 2005; Stoop et al., 2007; König et al., 2008). However, the repeatability of MUN concentration (0.66) was higher than the corresponding values of 0.43 reported previously (Stoop et al., 2007). It is probable that this difference is related to a greater variability in dietary CP concentration on commercial farms compared with diets fed in controlled experiments. Dietary $\mathrm{CP}$ concentration is the most important dietary factor affecting MUN concentration (Broderick and Clayton, 1997; Nousiainen et al., 2004). In practice, diet composition can vary between test-days, thereby lowering the repeatability of MUN determination. For experimental data used in this evaluation, some variation

Table 5. Description of the intake, excretion, and retention of N, and total-tract nutrient digestibility for the production data set derived from 21 milk-production trials (production data set, $\mathrm{n}=443$ )

\begin{tabular}{lcrcc}
\hline Item & Mean & SD & Minimum & Maximum \\
\hline N, g/d & & & & \\
Intake & 531 & 104.2 & 259 & 767 \\
Feces & 172 & 38.7 & 68 & 266 \\
Milk & 158 & 32.6 & 62 & 247 \\
Urine & 193 & 52.1 & 48 & 379 \\
Retained ${ }^{1}$ & 8 & 12.2 & -40 & 37 \\
Total-tract digestibility, g/kg & 713 & 31.9 & 607 & 827 \\
OM & 614 & 65.0 & 404 & 790 \\
NDF & 676 & 42.7 & 525 & 854 \\
CP & & & \\
\hline
\end{tabular}

${ }^{1}$ Estimated from calculated ME balance assuming a CP concentration of $160 \mathrm{~g} / \mathrm{kg}$ of BW change, $1.0 \mathrm{~kg}$ of $\mathrm{BW}$ gain is equivalent to $34 \mathrm{MJ}$ of $\mathrm{ME}$, and $1.0 \mathrm{~kg}$ of BW loss is equivalent to $28 \mathrm{MJ}$ of ME (MTT, 2013). 
Table 6. Influence of animal factors on MUN concentration $(\mathrm{mg} / \mathrm{dL})$ in lactating cows estimated by mixed-model regression analysis $(\mathrm{MUN}=$ $\left.A+B X_{1}+C X_{2}\right)$ of the production data set derived from 21 milk-production trials $(\mathrm{n}=1,804)^{1}$

\begin{tabular}{|c|c|c|c|c|c|c|c|c|c|c|}
\hline$X_{1}$ & $X_{2}$ & $A^{2}$ & $\mathrm{SE}$ & $B$ & $\mathrm{SE}$ & $P$-value & $C^{2}$ & $\mathrm{SE}$ & Residual & $\mathrm{AICc}^{3}$ \\
\hline ECM & & 9.8 & 0.42 & 0.065 & 0.012 & $<0.001$ & & & 3.54 & 7,997 \\
\hline BW & & 12.4 & 0.54 & -0.0009 & 0.0008 & 0.25 & & & 3.65 & 8,036 \\
\hline DIM & DIM × DIM & $10.9^{4}$ & 0.44 & 1.69 & 0.470 & $<0.001$ & -0.662 & 0.147 & 3.60 & 8,013 \\
\hline MY & $\mathrm{PC}$ & 14.8 & 0.92 & 0.030 & 0.013 & 0.02 & -0.115 & 0.019 & 3.41 & 7,951 \\
\hline
\end{tabular}

${ }^{1} \mathrm{MY}=$ milk yield, $\mathrm{kg} / \mathrm{d} ; \mathrm{ECM}, \mathrm{kg} / \mathrm{d} ; \mathrm{FC}=$ milk fat concentration, $\mathrm{g} / \mathrm{kg} ; \mathrm{PC}=$ milk protein concentration, $\mathrm{g} / \mathrm{kg} ; \mathrm{BW}$ is in $\mathrm{kg}$.

${ }^{2}$ All $P$-values $<0.001$.

${ }^{3} \mathrm{AICc}=$ Akaike's information criterion with correction.

${ }^{4}$ Coefficients calculated for DIM/100.

in dietary $\mathrm{CP}$ concentration may exist between cows fed the same diet, because in most of the production trials, concentrates were fed on a flat-rate basis and forages were offered ad libitum. Consequently, dietary $\mathrm{CP}$ concentration may fluctuate between individual cows if the $\mathrm{CP}$ concentration of concentrates and forages differ. For the production data set, variation due to cow within experiment explained only $0.1 \%$ of total variance in dietary $\mathrm{CP}$ concentration and, therefore, is not a major factor contributing to between-animal variation in MUN concentration $(\mathrm{CV}=0.13$; Table 3). Furthermore, between-cow and residual variance did not change when dietary $\mathrm{CP}$ concentration was included in the model predicting MUN concentration, which also suggests that the difference in dietary $\mathrm{CP}$ concentration was a small contributor to phenotypic variation in MUN concentration.

\section{Influence of Animal Factors on Milk Urea Concentration}

Use of a mixed model in the evaluation of production and flow data sets allowed the effects of diet within study and period within study to be removed, and therefore, only between-animal differences in $\mathrm{N}$ digestion and metabolism contributed to the relationship between milk yield and MUN concentration. Reports on the strength of the relationship between milk yield and MUN concentration based on measurements of individual animals have been inconsistent. In some studies, a negative association between MUN concentration and milk yield has been reported (Broderick and Clayton, 1997; Stoop et al., 2007). In contrast, increases in FCM yield of multiparous cows up to $58 \mathrm{~kg} / \mathrm{d}$ were accompanied by an increase in MUN concentration (Wattiaux et al., 2005). A positive (0.13) phenotypic correlation between MUN and milk yield has also been reported (König et al., 2008). However, a close positive association between MUN concentration and milk yield observed in com- mercial herds may simply reflect higher-yielding cows consuming diets containing more CP. In the evaluation of the production data set, the effect of milk yield on MUN concentration, although significant, was quantitatively small (i.e., $0.069 \mathrm{mg} / \mathrm{dL}$ per unit $\mathrm{kg} / \mathrm{d}$; Table 6). This was exemplified by a single standard deviation difference in milk yield between cows within Diet(Exp) and Period(Exp) (i.e., $4.25 \mathrm{~kg} / \mathrm{d}$ or $14.3 \%$ of average milk yield; Table 1 ) corresponding to a $\pm 2.5 \%$ difference in MUN concentration (i.e., $0.069 \times 4.25 / 12.0 \%$; Table 1). Using the relationship between dietary CP and MUN concentrations based on a meta-analysis of treatment means $(\mathrm{MUN}, \mathrm{mg} / \mathrm{dL}=-14.2+0.17 \times$ dietary $\mathrm{CP}$ concentration, $\mathrm{g} / \mathrm{kg}$ of $\mathrm{DM}$; Nousiainen et al., 2004), and the relationship between milk yield and MUN concentration for the production data set (MUN, $\mathrm{mg} / \mathrm{dL}=9.8+0.069 \times$ milk yield, $\mathrm{kg} / \mathrm{d}$; Table 6 ), then the changes in MUN concentration accompanying a 1-kg increase in milk yield can be calculated to correspond to a $0.4 \mathrm{~g} / \mathrm{kg}$ increase in dietary $\mathrm{CP}$ concentration. Such comparisons suggest that a $1-\mathrm{kg}$ increase in milk yield would require an additional $8 \mathrm{~g}$ of dietary $\mathrm{CP}$ for gluconeogenesis in lactating cows with a DMI of 20 $\mathrm{kg}$, assuming that deamination and use of AA carbon for glucose synthesis have the same influence on MUN concentration as an increase in CP intake. The positive effect of milk yield on MUN concentration and negative effect of milk protein concentration are in line with this suggestion.

A negative association between MUN and milk protein concentration is consistent with previous evaluations based on treatment means (Nousiainen et al., 2004). However, other studies have reported positive phenotypic and genotypic associations between MUN and milk protein concentration (Stoop et al., 2007). The reasons for a negative relationship between the concentration of MUN and milk protein are not obvious, particularly when milk protein concentration was not associated with MNE (Table 7) or UN output 
Table 7. Influence of animal factors on the efficiency of $\mathrm{N}$ utilization for milk production (MNE; milk $\mathrm{N} / \mathrm{N}$ intake, $\mathrm{g} / \mathrm{kg}$ ) in lactating cows estimated by mixed-model regression analysis $\left(\mathrm{MNE}=A+B X_{1}+C X_{2}+D X_{3}+E X_{4}\right)$ of the production data set derived from 21 milk-production trials $(\mathrm{n}=1,804)^{1}$

\begin{tabular}{|c|c|c|c|c|c|c|c|c|c|c|c|c|c|c|c|}
\hline$X_{1}$ & $X_{2}$ & $X_{3}$ & $X_{4}$ & $A^{2}$ & $\mathrm{SE}$ & $B^{2}$ & $\mathrm{SE}$ & $C^{2}$ & $\mathrm{SE}$ & $D^{2}$ & SE & $E^{2}$ & SE & Residual & $\mathrm{AICc}^{3}$ \\
\hline MY & & & & 218 & 4.2 & 2.61 & 0.115 & & & & & & & 441 & 16,703 \\
\hline MUN & & & & 313 & 4.3 & -1.57 & 0.291 & & & & & & & 587 & 17,124 \\
\hline MY & MUN & & & 242 & 4.7 & 2.77 & 0.115 & -2.40 & 0.256 & & & & & 435 & 16,625 \\
\hline MY & $\mathrm{MY} \times \mathrm{MY}$ & & & 155 & 11.3 & 6.91 & 0.729 & -0.070 & 0.0118 & & & & & 430 & 16,668 \\
\hline MY & $\mathrm{MY} \times \mathrm{MY}$ & MUN & & 173 & 11.1 & 7.64 & 0.720 & -0.080 & 0.0116 & -2.54 & 0.254 & & & 423 & 16,579 \\
\hline MY & $\mathrm{MY} \times \mathrm{MY}$ & BW & & 218 & 12.3 & 6.24 & 0.706 & -0.054 & 0.0115 & -0.095 & 0.0084 & & & 399 & 16.547 \\
\hline MY & $\mathrm{MY} \times \mathrm{MY}$ & DIM & & 169 & 11.8 & 6.70 & 0.728 & -0.070 & 0.0117 & -0.059 & 0.0156 & & & 426 & 16,655 \\
\hline MY & $\mathrm{MY} \times \mathrm{MY}$ & MUN & BW & 238 & 12.0 & 7.00 & 0.694 & -0.064 & 0.0112 & -2.65 & 0.245 & -0.100 & 0.0083 & 388 & 16,442 \\
\hline
\end{tabular}

${ }^{1} \mathrm{MY}=$ milk yield, $\mathrm{kg} / \mathrm{d} ; \mathrm{MUN}$ is in $\mathrm{mg} / \mathrm{dL} ; \mathrm{BW}$ is in $\mathrm{kg}$.

${ }^{2}$ All $P$-values $\leq 0.001$

${ }^{3} \mathrm{AICc}=$ Akaike's information criterion with correction.

Table 8. Influence of animal factors on the efficiency of $\mathrm{N}$ utilization for milk production (MNE; milk N/N intake, g/kg) estimated by mixed-model regression analysis (MNE $=A$ $+B X_{1}+C X_{2}+D X_{3}$ ) of the flow data set derived from 20 metabolic studies in lactating cows where the concentration of both MUN and rumen ammonia nitrogen were determined $(\mathrm{n}=309)^{1}$

\begin{tabular}{|c|c|c|c|c|c|c|c|c|c|c|c|c|c|}
\hline$X_{1}$ & $X_{2}$ & $X_{3}$ & $A^{2}$ & $\mathrm{SE}$ & $B^{2}$ & $\mathrm{SE}$ & $C$ & $\mathrm{SE}$ & $P$-value & $D^{2}$ & $\mathrm{SE}$ & Residual & $\mathrm{AICc}^{3}$ \\
\hline MY & & & 178 & 8.7 & 4.3 & 0.32 & & & & & & 491 & 2,982 \\
\hline RAN & & & 331 & 7.7 & -4.1 & 0.73 & & & & & & 723 & 3,094 \\
\hline MUN & & & 327 & 10.2 & -3.3 & 0.89 & & & & & & 762 & 3,110 \\
\hline RAN & MUN & & 342 & 10.3 & -3.6 & 0.78 & -1.5 & 0.94 & 0.10 & & & 721 & 3,094 \\
\hline MY & RAN & & 215 & 9.7 & 4.2 & 0.31 & -3.6 & 0.53 & $<0.001$ & & & 453 & 2,941 \\
\hline MY & MUN & & 219 & 9.5 & 4.7 & 0.30 & -5.1 & 0.65 & $<0.001$ & & & 482 & 2,932 \\
\hline MY & RAN & MUN & 233 & 9.9 & 4.5 & 0.30 & -2.4 & 0.56 & $<0.001$ & -3.8 & 0.70 & 451 & 2,916 \\
\hline
\end{tabular}

${ }^{1} \mathrm{MY}=$ milk yield, $\mathrm{kg} / \mathrm{d} ; \mathrm{RAN}=$ rumen ammonia $\mathrm{N}$ concentration, $\mathrm{mg} / \mathrm{dL} ; \mathrm{MUN}$ is in $\mathrm{mg} / \mathrm{dL}$.

${ }^{2}$ All $P$-values $\leq 0.001$.

${ }^{3} \mathrm{AICc}=$ Akaike's information criterion with correction. 
Table 9. Influence of animal factors on urinary $\mathrm{N}(\mathrm{UN})$ excretion $(\mathrm{g} / \mathrm{d})$ in lactating cows estimated by mixed-model regression analysis $(\mathrm{UN}=$ $\left.A+B X_{1}+C X_{2}+D X_{3}\right)$ of the production data set derived from 10 milk-production trials $(\mathrm{n}=443)^{1}$

\begin{tabular}{|c|c|c|c|c|c|c|c|c|c|c|c|c|c|}
\hline$X_{1}$ & $X_{2}$ & $X_{3}$ & A & $\mathrm{SE}$ & $P$-value & $B^{2}$ & $\mathrm{SE}$ & $C^{2}$ & $\mathrm{SE}$ & $D^{2}$ & $\mathrm{SE}$ & Residual & $\mathrm{AICc}^{3}$ \\
\hline MUN & & & 126 & 7.6 & $<0.001$ & 5.57 & 0.574 & & & & & 567 & 4,301 \\
\hline MY & MUN & & 49 & 11.1 & $<0.001$ & 2.68 & 0.309 & 5.27 & 0.534 & & & 490 & 4,234 \\
\hline MY & MUN & DIM & -4 & 14.8 & 0.77 & 3.44 & 0.339 & 5.78 & 0.520 & 0.205 & 0.0423 & 487 & 4,214 \\
\hline MY & MUN & BW & -27 & 12.5 & 0.04 & 1.59 & 0.293 & 4.87 & 0.473 & 0.194 & 0.0167 & 342 & 4,124 \\
\hline DMI & MUN & BW & -29 & 12.3 & 0.03 & 4.27 & 0.669 & 4.32 & 0.462 & 0.136 & 0.0200 & 314 & 4,112 \\
\hline
\end{tabular}

${ }^{1} \mathrm{MY}=$ milk yield, $\mathrm{kg} / \mathrm{d}$; MUN is in $\mathrm{mg} / \mathrm{dL} ; \mathrm{BW}$ is in $\mathrm{kg} / \mathrm{d} ; \mathrm{DMI}$ is in $\mathrm{kg} / \mathrm{d}$.

${ }^{2}$ All $P$-values $\leq 0.001$.

${ }^{3} \mathrm{AICc}=$ Akaike's information criterion with correction.

(Table 9). One possible explanation is that increased milk protein concentration lowers the amount of glucose required for the synthesis of other milk components.

In the present evaluation, the influence of DIM on MUN concentration was quadratic with a peak at 120 and $132 \mathrm{~d}$ for primiparous and multiparous cows, respectively. A similar quadratic association with a peak between the second and third month of lactation was reported for commercial herds (Stoop et al., 2007). In contrast, the influence of stage of lactation on MUN concentration has been reported to mirror that for milk yield in primiparous cows (Bastin et al., 2009).

\section{Efficiency of Nitrogen Utilization and Milk Urea Concentration}

Use of individual cow data indicated that increases in MUN were associated with a decrease in MNE, a finding consistent with that based on treatment means (Nousiainen et al., 2004). However, a mean decrease of $1.57 \mathrm{~g} / \mathrm{kg}$ in MNE per $\mathrm{mg} / \mathrm{dL}$ increase in MUN concentration is considerably lower than a corresponding value of $7.3 \mathrm{~g} / \mathrm{kg}$ reported previously (Nousiainen et al., 2004). Evaluation of treatment means has shown that dietary $\mathrm{CP}$ concentration is the main determinant of MNE in lactating cows (Huhtanen and Hristov, 2009). The current analysis examined the influence of between-cow variation on the relationship between MNE and MUN concentration based on measurements for individual cows using a mixed model that allowed the effect of diet and period to be removed, i.e., for cows fed the same diet at the same time. Higher dietary $\mathrm{N}$ intakes are known to increase exponentially the proportion of $\mathrm{N}$ excreted in urine (Kebreab et al., 2002). At a constant DMI, more than $80 \%$ of the incremental increase in $\mathrm{N}$ intake was lost in urine (Huhtanen et al.,

Table 10. Influence of animal factors on the association between rumen ammonia N (RAN) concentration and total-tract OM digestibility (OMD; $\mathrm{n}=414$ ) and NDF digestibility (NDFD; $\mathrm{n}=414$ ) or on the association of MUN concentration with OMD $(\mathrm{n}=301)$ estimated by mixedmodel regression analysis (OMD and NDFD $=A+B X_{1}+C X_{2}+D X_{3}$ ) of the flow data set derived from 26 metabolic studies in lactating cows ${ }^{1}$

\begin{tabular}{|c|c|c|c|c|c|c|c|c|c|c|c|c|}
\hline$X_{1}$ & $X_{2}$ & $X_{3}$ & $A^{2}$ & $\mathrm{SE}$ & $B^{3}$ & $\mathrm{SE}$ & $C^{2}$ & SE & $D^{2}$ & SE & Residual & $\mathrm{AICc}^{4}$ \\
\hline RAN & & & 725 & 4.5 & 1.4 & 0.42 & & & & & 347 & 3,872 \\
\hline RAN & $\mathrm{RAN} \times \mathrm{RAN}$ & & 711 & 6.3 & 4.4 & 1.49 & -0.14 & 0.042 & & & 351 & 3,867 \\
\hline RAN & $\mathrm{RAN} \times \mathrm{RAN}$ & DMI & 773 & 11.0 & 4.7 & 1.01 & -0.16 & 0.041 & -3.2 & 0.49 & 308 & 3,827 \\
\hline \multicolumn{13}{|l|}{ NDFD } \\
\hline RAN & & & 610 & 8.0 & 3.9 & 0.65 & & & & & 750 & 4,258 \\
\hline \multicolumn{13}{|l|}{ OMD } \\
\hline MUN & & & 718 & 6.6 & 1.8 & 0.73 & & & & & 364 & 2,823 \\
\hline MUN & MUN $\times$ MUN & & 684 & 13.2 & 8.9 & 2.48 & -0.34 & 0.112 & & & 373 & 2,817 \\
\hline MUN & DMI & & 770 & 13.9 & 1.8 & 0.71 & -2.7 & 0.63 & & & 336 & 2,807 \\
\hline MUN & MUN $\times$ MUN & DMI & 737 & 18.2 & 8.1 & 2.45 & -0.30 & 0.111 & -2.6 & 0.62 & 342 & 2,803 \\
\hline
\end{tabular}

${ }^{1} \mathrm{RAN}$ concentration $=\mathrm{mg} / \mathrm{dL} ; \mathrm{DMI}$ is in $\mathrm{kg} / \mathrm{d} ; \mathrm{MUN}$ is in $\mathrm{mg} / \mathrm{dL}$.

${ }^{2}$ All $P$-values $\leq 0.001$.

${ }^{3}$ All $P$-values $\leq 0.02$.

${ }^{4} \mathrm{AICc}=$ Akaike's information criterion with correction. 
2008), which explains the strong negative relationship between MNE and MUN concentration. Systematic addition of animal factors (milk yield, BW, and DIM) decreased the residual variance in predictions of MNE from MUN concentration. This suggests that the relationship between MNE and MUN concentration was influenced by factors related to the contribution for maintenance versus productive requirements or nutrient repartitioning. Even though a strong relationship existed between MUN concentration and MNE, it remains unclear whether measurements of MUN concentration can be used to reliably rank individual cows for MNE under commercial conditions. The estimate of the Cow(Exp) variance component for MUN concentration corresponded to a standard deviation value of $1.58 \mathrm{mg} / \mathrm{dL}$ (Table 3), whereas the coefficients of MUN concentration averaged $-2.53 \mathrm{~g}$ of milk $\mathrm{N} / \mathrm{kg}$ of $\mathrm{N}$ intake in the multivariate models (Table 7). Thus, for each $1.58-\mathrm{mg} / \mathrm{dL}$ increase in MUN concentration, MNE had a concomitant decrease of $4.0 \mathrm{~g} / \mathrm{kg}$, a value equivalent to only $1.4 \%$ of the mean MNE determined in the milk-production trials (Table 1 ). Whereas a moderate heritability for MUN concentration of between 0.13 and 0.22 has been reported (Mitchell et al., 2005; Stoop et al., 2007; König et al., 2008; Bastin et al., 2009), the breeding value for MUN does not appear to be related to the efficiency of $\mathrm{N}$ utilization (Vallimont et al., 2011). Selecting for MUN concentration does not appear a useful phenotyping tool for improving MNE, but measurements of MUN concentration on a herd basis allow fine tuning of the diet for improving digestibility or MNE. It is difficult to adjudge whether measurements of MUN concentration for individual cows can be used to reliably rank cows for efficient $\mathrm{N}$ utilization.

In the flow data set, the statistical model including both MUN and RAN concentrations explained more of the variation in MNE compared with either variable alone based on AICc calculations. Concentrations of RAN and MUN and excretion of UN are decreased in cows fed diets of lower ruminal protein degradability. Furthermore, increases in absorbed AA in excess of requirements for milk protein or body-tissue synthesis are catabolized and converted to urea in the liver. This may well explain the close association between the concentrations of MUN and dietary CP across a wide range of diets, despite differences in ruminal or hostanimal $\mathrm{N}$ metabolism. For example, replacing grass silage with red-clover silage resulted in a more efficient utilization of $\mathrm{N}$ in the rumen and smaller changes in RAN concentration than would be expected based on the higher dietary $\mathrm{CP}$ concentration, but the increase in NAN flow at the omasum was not used for milk protein synthesis (Vanhatalo et al., 2009).

\section{UN Excretion}

In the absence of direct measurements of urinary output for the 10 milk-production trials where totaltract digestibility was determined, UN excretion was calculated based on estimates of $\mathrm{N}$ retention derived from calculated ME balance (Table 5). Although the lack of direct observations may be criticized, ample evidence exists that $\mathrm{N}$ balance studies may overestimate $\mathrm{N}$ retention in lactating dairy cows. For example, a meta-analysis based on data from 35 studies reported a mean $\mathrm{N}$ balance of $+39 \mathrm{~g} / \mathrm{d}$ (Spanghero and Kowalski, 1997). A more recent appraisal across 123 diets indicated a mean $\mathrm{N}$ balance of $+30 \mathrm{~g} / \mathrm{d}$ (Spek et al., 2013). Assuming a mean muscle CP concentration of $160 \mathrm{~g} / \mathrm{kg}$, a net daily $\mathrm{N}$ accretion of $30 \mathrm{~g} / \mathrm{d}$ corresponds to a $1.17 \mathrm{~kg} / \mathrm{d}$ gain of lean body mass. Several factors may contribute to errors in the determination of $\mathrm{N}$ balance including ammonia $\mathrm{N}$ losses from feces and urine, excretion of $\mathrm{N}$ in urine as nitrate that is not recovered in Kjeldahl analysis, and $\mathrm{N}$ losses in scurf (Spanghero and Kowalski, 1997; Reynolds and Kristensen, 2008). It is possible that $\mathrm{N}$ balance calculated from estimated ME balance may result in more accurate estimates of UN excretion. However, the approach used in the present evaluation does not take into account variation in feed efficiency that can introduce errors in the estimation of ME balance. Both the residual variance (342 vs. 404) and $\mathrm{AICc}(4,124$ vs. 4,174$)$ for UN excretion decreased using estimated $\mathrm{N}$ retention rather than assuming a zero $\mathrm{N}$ balance in a 3-variable (milk yield, MUN concentration, and BW; Table 9) model, which would tend to suggest that estimated $\mathrm{N}$ balance was correlated with true $\mathrm{N}$ retention. For all other models tested (Table 9), a better fit of the data was obtained when $\mathrm{N}$ retention was estimated from calculated $\mathrm{ME}$ balance compared with estimates based on the assumption of zero $\mathrm{N}$ balance.

For individual cows, UN excretion increased $5.8 \mathrm{~g} / \mathrm{d}$ per $1 \mathrm{mg} / \mathrm{dL}$ increase in MUN concentration (Table 9 ), an estimate considerably lower than values between 12.8 to $14.1 \mathrm{~g} / \mathrm{d}$ per $1 \mathrm{mg} / \mathrm{dL}$ change in MUN concentration estimated using models developed from treatment means (Nousiainen et al., 2004; Spek et al., 2013). Linear relationships between MUN concentration and UN output were found to differ between lactating Holstein and Jersey cows (Kauffman and St-Pierre, 2001). The influence of breed was attributed to differences in BW, and they developed a simple model using MUN $\times$ BW to predict UN output. In the present investigation, multivariate models with milk yield and BW as independent factors were used in addition to MUN concentration to estimate UN excretion. Both BW and 
milk yield are biologically relevant. Increased milk yield requires higher intakes and greater metabolism of $\mathrm{N}$ in body tissues. Maintenance protein requirements that are excreted as $\mathrm{N}$ in urine increase with BW (NRC, 2001). Even though between-cow differences were significant for UN output (Table 3), between-cow variability as adjudged from the estimate of the Cow(Exp) variance component corresponded to only $8.3 \%$ of the total variance (Table 3). Estimates of the Cow(Exp) variance component for MUN concentration corresponded to a standard deviation value of $1.58 \mathrm{mg} / \mathrm{dL}$ (Table 3), whereas the coefficients for MUN averaged $5.1 \mathrm{~g}$ of UN per $\mathrm{mg} / \mathrm{dL}$-unit change in MUN in the multivariate models (Table 9). Therefore, for each single standard deviation-unit increase in MUN, UN output had a concomitant increase of $8.0 \mathrm{~g} / \mathrm{d}$ equivalent to $4.1 \%$ of mean UN output (Table 5). Compared with the contributions of Exp (50.7\%) and Diet(Exp) (30.7\%) to total variance in UN output, the extent of variation due to between-animal differences of $8.3 \%$ is relatively minor. Across a wide range of diets, MUN concentrations are positively associated with UN output (Jonker et al., 1998; Kauffman and St-Pierre, 2001; Nousiainen et al., 2004). Much less is known about the correlation between the breeding values for MUN concentration with MNE or UN output. The available evidence suggests that the genetic correlation between MUN and MNE is weak $(-0.10)$ and does differ significantly from zero (Vallimont et al., 2011). Given that decreases in MNE are associated with increased UN excretion (Kebreab et al., 2002), it seems reasonable to assume that genetic differences in breeding values for MUN concentration would have little influence on UN output. Given the relatively small extent of variation in UN excretion because of differences between animals, the selection of cows with an inherently low MUN concentration might not be an efficient means for lowering $\mathrm{N}$ losses into the environment. Optimizing feeding and management practices appears to offer much more potential for lowering the environmental impact of milk production.

\section{Microbial Nitrogen Supply and Diet Digestibility}

This is the first attempt to evaluate the association of between-animal differences in RAN and MUN concentrations with nutrient digestion in lactating cows. Within the range of values in the data sets examined, no association of between-animal differences in RAN concentration with microbial protein synthesis was found, whereas a positive relationship was identified with variability in RAN concentration and total-tract OMD (Table 10). Comparison of these associations suggests that the RAN concentration for optimal digestion is higher than that required for optimal microbial synthesis. Analysis of treatment means (Oldham, 1984; Nousiainen et al., 2009) has shown that increases in dietary $\mathrm{CP}$ concentration by replacing energy supplements with protein supplements were associated with improvements in diet digestibility. However, mechanisms other than increases in RAN concentration might explain the improvement in diet digestion to increases in dietary $\mathrm{CP}$ concentration, including the stimulation of cellulolytic bacterial activity by preformed AA and peptides (Atasoglu et al., 2001). Results of in vivo, in situ, and in vitro studies of urea supplementation have been unable to define the RAN requirements of rumen microorganisms to maximize ruminal digestion. Diet digestibility was improved through increases in RAN concentration by urea supplementation in vivo (KangMeznarich and Broderick, 1981; Balcells et al., 1993), in situ (Mehrez et al., 1977; Erdman et al., 1986), and in vitro (Wallace, 1979). Evaluation of the flow data set indicated that the positive association between RAN concentration and total-tract OMD and NDFD was not related to intake level, because the regression coefficient for RAN concentration did not change when DMI was included in the model. The negative influence of DMI on total-tract OMD was similar to that reported based on the analysis of treatment means (Huhtanen et al., 2009). Earlier reports concluded that RAN concentrations required to maximize digestion are at least as high as those required for maximum microbial synthesis, and that the optimal concentrations depend on the fermentability of the diet (Schwab et al., 2005). On the basis of published data and the findings from this evaluation, it appears that increasing RAN concentrations have a positive effect on digestibility, irrespective of whether the changes are due to urea supplementation or arise from differences between animals. In the flow data set, the improvement in total-tract OMD with increased RAN concentration was explained entirely by increases in $\operatorname{NDFD}(3.9 \times 0.399=1.56 \sim 1.40)$.

The reasons for the relatively large between-animal variation in RAN concentration $(\mathrm{CV}=0.14$; Table 4$)$ are not clear. Variance may be related to differences in rumen microbial populations, the relative size of protozoal communities in particular. A quantitative metaanalysis of data from studies involving defaunation indicated that concentrations of RAN were markedly higher in faunated than defaunated animals (168 vs. $117 \mathrm{mg}$ of $\mathrm{NH}_{3}-\mathrm{N} / \mathrm{L}$; Eugène et al., 2004). Furthermore, the difference in RAN concentration due to defaunation was also associated with a higher total-tract OM $(675$ vs. $659 \mathrm{~g} / \mathrm{kg}$ ) and NDF (611 vs. $554 \mathrm{~g} / \mathrm{kg}$ ) digestibility (Eugène et al., 2004). Large between-animal variation in rumen protozoal populations have been reported for sheep fed the same diet (Clarke et al., 1982), but it is not known whether between-animal variation in 
protozoal populations has the same influence on RAN concentration and digestibility compared with complete defaunation. Nevertheless, RAN concentration had a negative $(P<0.001)$ association with the ratio of propionate to butyrate in rumen VFA in the flow data set (data not presented), supporting the hypothesis that between-cow variability in RAN concentration was, at least in part, related to differences in protozoal numbers. Comparisons of faunated compared with defaunated animals also indicated that the presence of protozoa in the rumen was associated with lower molar proportions of propionate (202 vs. $231 \mathrm{mmol} / \mathrm{mol})$ and higher molar butyrate proportions (126 vs. $109 \mathrm{mmol} /$ mol; Eugène et al., 2004).

\section{CONCLUSIONS}

Concentrations of MUN and RAN varied considerably between cows when the effects due to diet and period were controlled by a statistical model. Increases in MUN or RAN concentration were negatively associated with the efficiency of $\mathrm{N}$ utilization but positively related to UN excretion. Concentration of RAN was positively associated with diet digestibility, but the concentration for optimal diet digestibility appears to be higher than that required for maximizing microbial protein supply. Between-cow differences in RAN concentration, although significant, had no influence on microbial $\mathrm{N}$ flow or on the efficiency of microbial protein synthesis. Overall, improvements in management and a closer control over diet composition relative to requirements appear to have greater potential to improve the efficiency of $\mathrm{N}$ utilization of lactating cows than selection of cows with an inherently low MUN concentration.

\section{ACKNOWLEDGMENTS}

The authors express their appreciation to colleagues involved in the original milk-production trials and detailed metabolic studies. This work was supported by RuminOmics (Project no. 289319 of the European Community 7th Framework Programme: Food, Agriculture, Fisheries and Biotechnology) and The Swedish Research Council Formas (Project no. 220-2011-1247).

\section{REFERENCES}

Aguilar, M., M. D. Hanigan, H. A. Tucker, B. L. Jones, S. K. Garbade, M. L. McGilliard, C. C. Stallings, K. F. Knowlton, and R. E. James. 2012. Cow and herd variation in milk urea nitrogen concentrations in lactating dairy cattle. J. Dairy Sci. 95:7261-7268.

Atasoglu, C., C. J. Newbold, and R. J. Wallace. 2001. Incorporation of ${ }^{15} \mathrm{~N}$ ammonia by the cellulolytic ruminal bacteria Fibrobacter succinogenes BL2, Ruminococcus albus SY3, and Ruminococcus flavefaciens 17. Appl. Environ. Microbiol. 67:2819-2822.
Balcells, J., J. A. Guada, C. Castrillo, and J. Gasa. 1993. Rumen digestion and urinary excretion of purine derivatives in response to urea supplementation of sodium-treated straw fed to sheep. Br. J. Nutr. 69:721-732.

Bastin, C., L. Laloux, A. Gillon, F. Miglior, H. Soyeurt, H. Hammami, C. Bertozzi, and N. Gengler. 2009. Modeling milk urea of Walloon dairy cows in management perspectives. J. Dairy Sci. 92:3529-3540.

Broderick, G. A., and M. K. Clayton. 1997. A statistical evaluation of animal and nutritional factors influencing concentrations of milk urea nitrogen. J. Dairy Sci. 80:2964-2971.

Broderick, G. A., P. Huhtanen, S. Ahvenjärvi, S. M. Reynal, and K. J. Shingfield. 2010. Quantifying ruminal nitrogen metabolism using the omasal sampling technique in cattle-A meta-analysis. J. Dairy Sci. 93:3216-3230.

Clarke, R. T. J., M. Ulyatt, and A. John. 1982. Variation in numbers and mass of ciliate protozoa in the rumen of sheep fed chaffed alfalfa (Medicago sativa). Appl. Environ. Microbiol. 43:1201-1204.

Erdman, R. A., G. H. Proctor, and J. H. Vandersall. 1986. Effect of rumen ammonia concentration on in situ rate and extent of digestion of feedstuffs. J. Dairy Sci. 69:2312-2320.

Eugène, M., H. Archimède, and D. Sauvant. 2004. Quantitative metaanalysis on the effects of defaunation of the rumen on growth, intake and digestion in ruminants. Livest. Prod. Sci. 85:81-97.

Huhtanen, P., and A. N. Hristov. 2009. A meta-analysis of the effect of protein concentration and degradability on milk protein yield and milk $\mathrm{N}$ efficiency in dairy cows. J. Dairy Sci. 92:3222-3232.

Huhtanen, P., J. I. Nousiainen, M. Rinne, K. Kytölä, and H. Khalili. 2008. Utilization and partition of dietary nitrogen in dairy cows fed grass silage-based diets. J. Dairy Sci. 91:3589-3599.

Huhtanen, P., M. Rinne, and J. Nousiainen. 2009. A meta-analysis of feed digestion in dairy cows. 2. The effects of feeding level and diet composition on digestibility. J. Dairy Sci. 92:5031-5042.

Jonker, J. S., R. A. Kohn, and R. A. Erdman. 1998. Using milk urea nitrogen to predict nitrogen excretion and utilization efficiency in lactating dairy cattle. J. Dairy Sci. 81:2681-2692.

Jonker, J. S., R. A. Kohn, and J. High. 2002. Use of milk urea nitrogen to improve dairy cow diets. J. Dairy Sci. 85:939-946.

Kang-Meznarich, J. H., and G. A. Broderick. 1981. Effects of incremental urea supplementation on ruminal ammonia concentration and bacterial protein formation. J. Anim. Sci. 51:422-431.

Kauffman, A. J., and N. R. St-Pierre. 2001. The relationship of milk urea nitrogen to urine nitrogen excretion in Holstein and Jersey cows. J. Dairy Sci. 84:2284-2294.

Kebreab, E., J. France, J. A. Mills, R. Allison, and J. Dijkstra. 2002 A dynamic model of $\mathrm{N}$ metabolism in the lactating dairy cow and an assessment of impact of $\mathrm{N}$ excretion on the environment. J. Anim. Sci. 80:248-259.

Kohn, R. A., K. F. Kalscheur, and E. Russek-Cohen. 2002. Evaluation of models to predict urinary excretion and milk urea nitrogen. J. Dairy Sci. 85:227-233.

König, S., Y. M. Chang, U. U. Von Borstel, D. Gianola, and H. Simianer. 2008. Genetic and phenotypic relationships among milk urea nitrogen, fertility, and milk yield in Holstein cows. J. Dairy Sci. 91:4372-4382

Littell, R. C., G. A. Milliken, W. W. Stroup, R. D. Wolfinger, and O. Schabenberger. 2006. SAS for Mixed Models. 2nd ed. SAS Institute Inc., Cary, NC.

McCullough, H. 1967. The determination of ammonia in whole blood by direct colorimetric method. Clin. Chim. Acta 17:297-304

Mehrez, A. Z., E. R. Ørskov, and I. McDonald. 1977. Rates of rumen fermentation in relation to ammonia concentration. Br. J. Nutr. 38:437-443.

Mitchell, R. G., G. W. Rogers, C. D. Dechow, J. E. Vallimont, J. B. Cooper, U. Sander-Nielsen, and J. S. Clay. 2005. Milk urea nitrogen concentration: Heritability and genetic correlations with reproductive performance and disease. J. Dairy Sci. 88:4434-4440.

MTT. 2013. Rehutaulukot ja ruokintasuositukset (Feed tables and feeding recommendations). MTT Agrifood Research Finland, Jokioinen. Accessed Nov. 15, 2013. https://portal.mtt.fi/portal/ page/portal/Rehutaulukot/feed_tables_english. 
Nousiainen, J., M. Rinne, and P. Huhtanen. 2009. A meta-analysis of feed digestion in dairy cows. 1. The effects of forage and concentrate factors on total diet digestibility. J. Dairy Sci. 92:5019-5030.

Nousiainen, J., K. J. Shingfield, and P. Huhtanen. 2004. Evaluation of milk urea nitrogen as a diagnostic of protein feeding. J. Dairy Sci. 87:386-398.

NRC. 2001. Nutrient Requirements of Dairy Cattle. 7th rev. ed. Natl. Acad. Press, Washington, DC.

Oldham, J. D. 1984. Protein energy relationships in dairy cows. J. Dairy Sci. 67:1090-1114.

Reynolds, C. K., and N. B. Kristensen. 2008. Nitrogen recycling through the gut and the nitrogen economy of ruminants: An asynchronous symbiosis. J. Anim. Sci. 86:E293-E305.

Schwab, C. G., P. Huhtanen, C. W. Hunt, and T. Hvelplund. 2005. Nitrogen requirements of cattle. Pages 13-70 in Interactions Between Cattle and the Environment. R. Pfeffer and A. Hristov, ed. CAB Int., Oxfordshire, UK.

Sjaunja, L. O., L. Baevre, L. Junkkarinen, J. Pedersen, and J. Setälä. 1991. A Nordic proposal for an energy corrected milk (ECM) formula. Pages 156-157 in Recording of Animals - State of the Art 1990. EAAP Publ. 50. Perform. Centre Agric. Publ. Doc. (PUDOC), Wageningen, the Netherlands.

Spanghero, M., and Z. M. Kowalski. 1997. Critical analysis of N balance experiments with lactating cows. Livest. Prod. Sci. 52:113122.

Spek, J. W., J. Dijkstra, G. van Duinkerken, W. H. Hendriks, and A. Bannink. 2013. Prediction of urinary nitrogen and urinary urea nitrogen excretion by lactating dairy cattle in northwestern Europe and North America: A meta-analysis. J. Dairy Sci. 96:4310-4322.

St-Pierre, N. R. 2001. Integrating quantitative findings from multiple studies using mixed model methodology. J. Dairy Sci. 84:741-755.

Stoop, W. M., H. Bovenhuis, and J. A. M. van Arendonk. 2007. Genetic parameters for milk urea nitrogen in relation to milk production traits. J. Dairy Sci. 90:1981-1986.

Tamminga, S. 1992. Nutrition management of dairy cows as a contribution to pollution control. J. Dairy Sci. 75:345-357.

Vallimont, J. E., C. D. Dechow, J. M. Daubert, M. W. Dekleva, J. W. Blum, C. M. Barlieb, W. Liu, G. A. Varga, A. J. Heinrichs, and C. R. Baumrucker. 2011. Short communication: Heritability of gross feed efficiency and associations with yield, intake, residual intake, body weight, and body condition score in 11 commercial Pennsylvania tie stalls. J. Dairy Sci. 94:2108-2113.

Van Keulen, J., and B. A. Young. 1977. Acid insoluble ash as a natural marker for digestibility studies. J. Anim. Sci. 44:282-287.

Vanhatalo, A., K. Kuoppala, S. Ahvenjärvi, and M. Rinne. 2009. Effects of feeding grass or red clover silage cut at two maturity stages in dairy cows. 1. Nitrogen metabolism and supply of amino acids. J. Dairy Sci. 92:5620-5633.

Wallace, R. J. 1979. Effects of ammonia concentration on the composition, hydrolytic activity and nitrogen metabolism of the microbial flora in the rumen. J. Appl. Bacteriol. 47:443-455.

Wattiaux, M. A., E. V. Nordheim, and P. Crump. 2005. Statistical evaluation of factors and interactions affecting Dairy Herd Improvement milk urea nitrogen in commercial Midwest dairy herds. J. Dairy Sci. 88:3020-3035.

\section{APPENDIX 1}

\section{List of Milk-Production Trials Contributing to the Production Data Set}

Bertilsson, J., and M. Murphy. 2003. Effects of feeding clover silage on feed intake, milk production and digestion in dairy cows. Grass Forage. Sci. 58:309-322.

Gidlund, H., M. Hetta, S. J. Krizsan, S. Lemosquet, and P. Huhtanen. 2013. Rapeseed or soybean meal to lactating cows fed grass silagebased diets. Pages 104-108 in Proc. 4th Nordic Feed Sci. Conf., SLU Repro, Uppsala, Sweden.
Heikkilä, T., E. Saarisalo, A.-M. Taimisto, and S. Jaakkola. 2010. Effects of dry matter and additive on wilted bale silage quality and milk production. Grassl. Sci. Europe 15:500-502.

Hetta, M., M. N. Tahir, S. J. Krizsan, A. Puranen, P. Lund, and P. Huhtanen. 2013. Effects of the inclusion of sodium hydroxide treated wheat on the voluntary feed intake and milk production in dairy cows. Livest. Sci. 154:103-111.

Höjer, A., S. Adler, K. Martinsson, S. K. Jensen, H. Steinshamn, E. Thuen, and A.-M. Gustavsson. 2012. Effect of legume-grass silages and $\alpha$-tocopherol supplementation on fatty acid composition and $\alpha$-tocopherol, $\beta$-carotene and retinol concentrations in organically produced bovine milk. Livest. Sci. 148:268-281.

Jaakkola, S., E. Saarisalo, and T. Heikkilä. 2009. Formic acid treated whole crop barley and wheat silages in dairy cow diets: Effects of crop maturity, proportion in the diet, and level and type of concentrate supplementation. Agric. Food Sci. 18:234-256.

Jaakkola, S., E. Saarisalo, T. Heikkilä, M. Nysand, A. Suokannas, M. Mäki, and A.-M. Taimisto. The effect of silage making technology on production and quality of milk. Grassl. Sci. Europe 13:642-644.

Kuoppala, K., M. Rinne, J. Nousiainen, and P. Huhtanen. 2008. The effect of cutting time of grass silage in primary growth and regrowth and the interactions between silage quality and concentrate level on milk production of dairy cows. Livest. Sci. 116:171-182.

Prestløkken, E., A. T. Randby, and T. Garmo. 2008. Effect of harvesting time and wilting on feed intake and production by dairy cows. Pages 849-851 in Biodiversity and Animal Feed: Future Challenges for Grassland Production. Proc. 22nd Gen. Meet. Eur. Grassl. Fed., SLU Repro, Uppsala, Sweden.

Randby, A. T., T. Garmo, M. Eknæs, and E. Prestløkken. 2008. Effects of grass silage chop length on intake and milk production by dairy cows. Pages 768-770 in Biodiversity and Animal Feed: Future Challenges for Grassland Production. Proc. 22nd Gen. Meet. Eur. Grassl. Fed., SLU Repro, Uppsala, Sweden.

Rinne, M., S. Jaakkola, K. Kaustell, T. Heikkilä, and P. Huhtanen. 1999. Silages harvested at different stages of grass growth versus concentrate foods as energy and protein sources in milk production. Anim. Sci. 69:251-263.

Saarisalo, E., S. Jaakkola, and P. Huhtanen. 2002. Effects of supplementing grass silage with protein on production of primiparous cows in late lactation. Grassl. Sci. Europe 7:594-595.

Sairanen, A. 2011. Säilörehun sulavuuden sekä väkirehu- ja valkuaistäydennyksen vaikutukset maidontuotannossa (The interaction between harvest time, concentrate supplementation and protein supplementation on milk production). Accessed Jan. 29, 2014. http:// hdl.handle.net/10138/27425.

Sairanen, A., and E. Juutinen. 2012. Nurmesta se kaikki lähtee! (Importance of forage quality in milk production) Karjatilan kannattava peltoviljely KARPE-hanke 2009-2012. Final report, pages 11-16. Page 12, experiments 2 and 5. Accessed Jan. 29, 2014. http://www.karpe.fi/materiaalit/karpekirjasto/paatosjulkaisu. pdf.

Sairanen, A., and E. Juutinen. 2013. Feeding value of late autumn cut timothy-meadow fescue silage under Northern conditions. Page 267 in The Role of Grasslands in a Green Future. Eur. Grassl. Fed., Borgarnes, Iceland.

Sairanen, A., J. I. Nousiainen, and H. Khalili. 1999. Korkean väkirehumäärän vaikutus maitotuotokseen ja tuotannon kannattavuuteen (The effect of protein and concentrate supplementation on milk production performance of dairy cows). Accessed Jan. 29, 2014. http://jukuri.mtt.fi/handle/10024/445044.

Shingfield, K. J., S. Jaakkola, and P. Huhtanen. 2002. Effect of forage conservation method, concentrate level and propylene glycol on intake, feeding behavior and milk production of dairy cows. Anim. Sci. 74:383-397.

Shingfield, K., S. Jaakkola, and P. Huhtanen. 2003. Comparison of heat-treated rapeseed expeller and solvent-extracted soya-bean meal protein supplements for dairy cows given grass silage-based diets. Anim. Sci. 77:305-317.

Wallsten, J. 2012. Så funkar vårvete som helsäd i norra Sverige (Spring wheat as whole crop silage in northern Sweden). Grovfoderkonfe- 
rensen 2013. Rapport 2:2013 Department of Agricultue for Northern Sweden, Swedish Univ. Agric. Sci., Umeå, Sweden.

\section{APPENDIX 2}

\section{List of Studies Contributing to the Flow Data Set}

Ahvenjärvi, S., E. Joki-Tokola, A. Vanhatalo, S. Jaakkola, and P. Huhtanen. 2006. Effects of replacing grass silage with barley silage in dairy cow diets. J. Dairy Sci. 89:1678-1687.

Ahvenjärvi, S., A. Vanhatalo, and P. Huhtanen. 2002. Supplementing barley or rapeseed meal to dairy cows fed grass-red clover silage: I. Rumen degradability and microbial flow. J. Anim. Sci. 80:2176-2187.

Ahvenjärvi, S, A. Vanhatalo, P. Huhtanen, and T. Varvikko. 1999. Effects of supplementation of a grass silage and barley diet with urea, rapeseed meal and heat-moisture treated rapeseed cake on omasal digesta flow and milk production in lactating dairy cows. Acta Agric. Scand., Sect. A, Anim. Sci. 49:179-189.

Ahvenjärvi, S., A. Vanhatalo, P. Huhtanen, and T. Varvikko. 2000. Determination of reticulo-rumen and whole-stomach digestion in lactating cows by omasal canal or duodenal sampling. Br. J. Nutr. 83:67-77.

Ahvenjärvi, S., A. Vanhatalo, and S. Jaakkola. 2005. Herneen ruokinnallinen arvo märehtijällä (Nutritional value of field pea in dairy cow diets). In: Herneen murskesäilöntä ja käyttö märehtijöiden ruokinnassa. Loppuraportti (Use of Ensiled Pea in Dairy Cow Diets. Final Report). MTT Agrifood Research Finland, Helsinki, Finland.

Ärölä, A., K. J. Shingfield, A. Vanhatalo, V. Toivonen, P. Huhtanen, and J. M. Griinari. 2002. Biohydrogenation shift and milk fat depression in lactating dairy cows fed increasing levels of fish oil. J. Dairy Sci. 85(Suppl. 1):143.

Bertilsson, J. 2012. Feeding a conserved mixture of grass with elevated sugar content and protein-rich legumes to dairy cows. Effects on milk production and rumen characteristics. (Unpublished).

Bertilsson, J., and M. Murphy. 2003. Effects of feeding clover silages on feed intake, milk production and digestion in dairy cows. Grass Forage Sci. 58:309-322.

Eriksson, T., L. Norell, and N. Nilsdotter-Linder. 2012. Nitrogen metabolism and milk production in dairy cows fed semi-restricted amounts of ryegrass-legume silage with birdsfoot trefoil (Lotus corniculatus L.) or white clover (Trifolium repens L.). Grass Forage Sci. $67: 546-558$

Eriksson, T. 2010. Nitrogen metabolism in dairy cows fed restricted amounts of grass-clover silage supplemented with seeds from narrow-leafed lupin or pea. Livest. Sci. 131:39-44.

Halmemies-Beauchet-Filleau, A., P. Kairenius, A. S. Ahvenjärvi, L. K. Crosley, S. Muetzel, P. Huhtanen, A. Vanhatalo, V. Toivonen, R. J. Wallace, and K. J. Shingfield. 2013. Effect of forage conservation method on ruminal lipid metabolism and microbial ecology in lactating cows fed diets containing a 60:40 forage to concentrate ratio. J. Dairy Sci. 96:2428-2447.

Kairenius P., V. Toivonen, S. Ahvenjärvi, A. Vanhatalo, P. Huhtanen, and K. J. Shingfield. 2007. Effect of fish oil alone or in combination with sunflower or linseed oil on rumen lipid metabolism and milk fat conjugated linoleic acid content in lactating cows. Page 67 in Proceedings of the II International Congress on Conjugated Linoleic Acid (CLA): From Experimental Models to Human Application. Tanka Village Resort, Villasimius (CA), Italy.

Korhonen, M., S. Ahvenjärvi, A. Vanhatalo, and P. Huhtanen, P. 2002. Supplementing barley or rapeseed meal to dairy cows fed grass-red clover silage: II. Amino acid profile of microbial fractions. J. Anim. Sci. 80:2188-2196.
Korhonen, M., A. Vanhatalo, and P. Huhtanen. 2002. Effect of protein source on amino acid supply, milk production, and metabolism of plasma nutrients in dairy cows fed grass silage. J. Dairy Sci. 85:3336-3351.

Korhonen, M. 2003. Amino acid supply and metabolism in relation to lactational performance of dairy cows fed grass silage based diets. PhD Diss. Univ. Helsinki, Dept. Anim. Sci. Publ. 68.

Krizsan, S. J., S. Ahvenjärvi, H. Volden, and G. A. Broderick. 2010. Estimation of rumen outflow in dairy cows fed grass silage-based diets by use of reticular sampling as an alternative to sampling from the omasal canal. J. Dairy Sci. 93:1138-1147.

Krizsan, S. J., G. A. Broderick, S. K. Nes, and H. Volden. 2010. Microbial protein flow in lactating and dry cows fed grass silages of different maturities. 3rd EAAP Int. Symp. Energy Protein Metab. Nutr., Parma, Italy.

Kuoppala, K., S. Ahvenjärvi, M. Rinne, and A. Vanhatalo. 2009. Effects of feeding grass or red clover cut at 2 maturity stages in Dairy cows. 2. Dry matter intake and cell wall digestion kinetics. J. Dairy Sci. 92:5634-5644.

Rinne, M., K. Kuoppala, S. Ahvenjärvi, and A. Vanhatalo. 2006. Rypsi soijaa parempi valkuaistäydennys puna-apilasäilörehua syötettäessä (Rapeseed expeller a better protein supplement than soybean expeller for dairy cows fed red clover silage). Suomen Maataloustieteellisen Seuran julkaisuja no 21. Ed. Anneli Hopponen. Accessed Feb. 3, 2014. http://www.smts.fi/esit06/1002.pdf.

Sairanen, A., H. Khalili, J. I. Nousiainen, S. Ahvenjärvi, and P. Huhtanen. 2005. The effect of concentrate supplementation on nutrient flow to the omasum in dairy cows receiving freshly cut grass. J. Dairy Sci. 88:1443-1453.

Shingfield, K. J., S. Ahvenjärvi, V. Toivonen, A. Ärölä, K. V. V. Nurmela, P. Huhtanen, and J. M. Griinari. 2003. Effect of dietary fish oil on biohydrogenation of fatty acids and milk fatty acid content in cows. Anim. Sci. 77:165-179.

Shingfield, K. J., S. Ahvenjärvi, V.Toivonen, A. Vanhatalo, P. Huhtanen, and J. M. Griinari. 2008. Effect of incremental levels of sunflower oil in the diet on ruminal lipid metabolism in lactating cows. Br. J. Nutr. 99:971-983.

Shingfield, K. J., S. Ahvenjärvi, V. Toivonen, P. Huhtanen, and J. M. Griinari. 2003. Synthesis of trans fatty acids and isomers of conjugated linoleic acid in the rumen of cows fed grass silage based diets supplemented with rapeseed, soybean, and linseed oil. J. Dairy Sci. 86(Suppl. 1):147.

Shingfield, K. J., P. Kairenius, A. Arölä, D. Paillard, S. Muetzel, S. Ahvenjärvi, A. Vanhatalo, P. Huhtanen, V. Toivonen, J. M. Griinari, and R. J. Wallace. 2012. Dietary fish oil supplements modify ruminal biohydrogenation, alter the flow of fatty acids at the omasum, and induce changes in the ruminal butyrivibrio population in lactating cows. J. Nutr. 142:1437-1448.

Shingfield, K. J., P. Kairenius, S. Ahvenjärvi, V. Toivonen, D. I. Givens, and R. J. Wallace. 2012. Effect of rapeseed lipid on ruminal lipid metabolism, rumen bacterial community, and milk fatty acid composition in lactating cows fed grass silage based diets. (Unpublished).

Shingfield, K .J., P. Kairenius, S. Ahvenjärvi, A. Vanhatalo, P. Huhtanen, D. I. Givens, and V. Toivonen. 2007. Effect of level and type of concentrate on ruminal lipid metabolism and milk fatty acid composition in lactating cows fed grass silage based diets. (Unpublished).

Tuori, M., M. Rinne, A. Vanhatalo, and P. Huhtanen. 2006. Omasal sampling technique in estimation of the site and extent of mineral absorption in dairy cows fed rapeseed and soybean expellers. Agric. Food Sci. 3:200-218

Vanhatalo, A., K. Kuoppala, S. Ahvenjärvi, and M. Rinne. 2009. Effects of feeding grass or red clover cut at 2 maturity stages in dairy cows. 2. Nitrogen metabolism and supply of amino acids. J. Dairy Sci. 92:5620-5633. 